\title{
Cross-Neutralization between Human and African Bat Mumps Viruses
}

\section{Hiroshi Katoh, Toru Kubota, Toshiaki Ihara, Ken Maeda, Makoto Takeda, Minoru Kidokoro}

Recently, a new paramyxovirus closely related to human mumps virus (MuV) was detected in bats. We generated recombinant MuVs carrying either or both of the fusion and hemagglutinin-neuraminidase bat virus glycoproteins. These viruses showed replication kinetics similar to human $\mathrm{MuV}$ in cultured cells and were neutralized efficiently by serum from healthy humans.

$\mathrm{M}$ any batborne paramyxoviruses closely related to mammalian paramyxoviruses recently have been identified, suggesting a possible risk for transmission of batborne paramyxoviruses to humans (1). Although no infectious virus has been isolated, the genome of a new paramyxovirus detected in an epauletted fruit bat (Epomophorus sp.) in the Democratic Republic of the Congo was closely related to the mumps virus $(\mathrm{MuV}$, genus Rubulavirus) (2).

Mumps is typically characterized by inflammation of the parotid glands but also can be accompanied by orchitis, aseptic meningitis, pancreatitis, and deafness (3). Mumps vaccines have been used worldwide for $>20$ years. MuV is serologically monotypic (4). The fusion (F) and hemagglutinin-neuraminidase $(\mathrm{HN})$ proteins, but not the small hydrophobic (SH) membrane protein, are the major targets of neutralizing (NT) antibodies $(5,6)$.

By using expression plasmids, in 2015, Kruger et al. determined that the envelope proteins of the new paramyxovirus African bat $\mathrm{MuV}(\mathrm{ABMuV})$ were serologically and functionally related to those of $\mathrm{MuV}$ (7). We generated infectious recombinant MuVs (rMuVs) carrying either or both of the $\mathrm{F}$ and $\mathrm{HN}$ glycoproteins of $\mathrm{ABMuV}$ to analyze their functions and serologic cross-reactivities in the context of virus infection.

\section{The Study}

A full-length genomic cDNA of the MuV Odate strain (pMuV-Odate) (8) was constructed, and the open reading frames of the $\mathrm{F}$ and $\mathrm{HN}$ genes were exchanged individually

Author affiliations: National Institute of Infectious Diseases,

Tokyo, Japan (H. Katoh, T. Kubota, M. Takeda, M. Kidokoro); Mie Hospital, Mie, Japan (T. Ihara); Yamaguchi University, Yamaguchi, Japan (K. Maeda)

DOI: http://dx.doi.org/10.32032/eid2204.151116 or together with those of $\mathrm{ABMuV}$, which were obtained by an artificial composition (GenBank accession no. HQ660095) (pMuV-Odate/ABMuV-F, /ABMuV-HN, and /ABMuV-FHN) (Figure 1, panel A). All infectious viruses were rescued by transfecting the plasmids pMuV-Odate, / $\mathrm{ABMuV}-\mathrm{F}, / \mathrm{ABMuV}-\mathrm{HN}$, and /ABMuV-FHN, along with helper plasmids, into BHK/T7-9 cells. Rescued viruses were propagated in Vero cells.

First, we examined syncytium formation in the Vero cells infected with all of the rMuVs (Figure 1, panel B). Although rOdate/ABMuV-F produced a cytopathic effect similar to that of rOdate, larger syncytia and severe cell detachment were observed in the cells infected with rOdate/ABMuV-HN and -FHN. To understand the basis for the enhanced syncytium formation by $\mathrm{rMuVs}$ carrying the $\mathrm{ABMuV} \mathrm{HN}$ protein, we expressed the $\mathrm{F}$ and $\mathrm{HN}$ proteins of the Odate and $\mathrm{ABMuV}$ strains using expression plasmids and examined for syncytium formation. Expression of the $\mathrm{ABMuV} \mathrm{HN}$ protein did not enhance syncytium formation when used in expression plasmids (Figure 1, panel C). These data were consistent with a previous study (7). The matrix protein was expressed together with the $\mathrm{HN}$ and F proteins because it can modulate syncytium formation. However, it did not affect the fusion activity. Therefore, the findings with infectious viruses appeared to differ from those obtained with expression plasmids (7).

All $\mathrm{rMuVs}$ were propagated efficiently in Vero cells (Figure 1, panel D). Although at 24 and $48 \mathrm{~h}$ postinfection the titers of rOdate/ABMuV-F were lower than those of the other 3 viruses, they later increased to $\approx 10^{8} \mathrm{PFU} / \mathrm{mL}$, which was comparable to the titers of rOdate and rOdate/ ABMuV-FHN. On the other hand, the peak titer of rOdate/ $\mathrm{ABMuV}-\mathrm{HN}$ was as low as $5 \times 10^{6} \mathrm{PFU} / \mathrm{mL}$. To determine whether the envelope proteins affect the cell tropisms of $\mathrm{MuV}$ in vitro, we evaluated the viral growth in human- and bat-derived cell lines. Human lung epithelial A549 and human monocytic THP-1 cells were used because epithelial cells and monocytes are the primary targets of $\mathrm{MuV}$ in vivo (9). In A549 cells, rOdate/ABMuV-HN showed the highest titer by up to $>10^{6} \mathrm{PFU} / \mathrm{mL}$ at $96 \mathrm{~h}$ postinfection (Figure 1, panel E). The other $3 \mathrm{rMuVs}$ also replicated well in A549 cells up to $\approx 10^{5} \mathrm{PFU} / \mathrm{mL}$, with rOdate/ABMuV-FHN showing much faster kinetics than the others. All 4 viruses grew to similar titers of up to $10^{7} \mathrm{PFU} / \mathrm{mL}$ in THP-1 cells (Figure 1, panel F). Growth was also efficient in the fruit bat-derived FBKT1 cells, although the peak titers of rOdate were lowest (Figure 1, panel G). Collectively, these 
findings using culture cells suggested that the envelope proteins are not a critical determinant of host specificity between $\mathrm{ABMuV}$ and $\mathrm{MuV}$.
We conducted NT assays and ELISA using human serum obtained from 12 healthy adults (18-58 years of age) under approval by the Ethical Committees of National

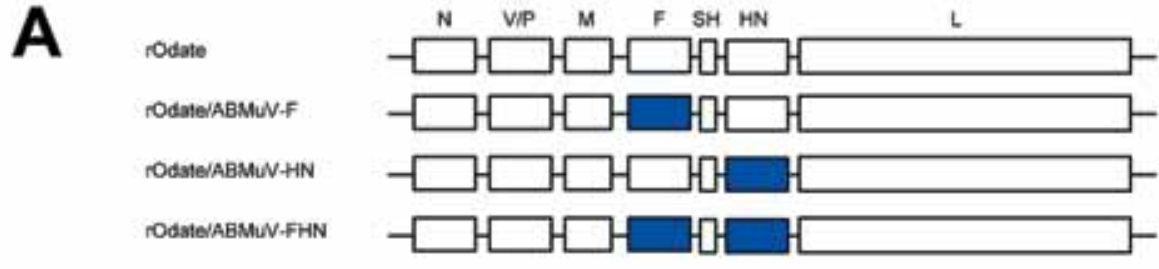

B
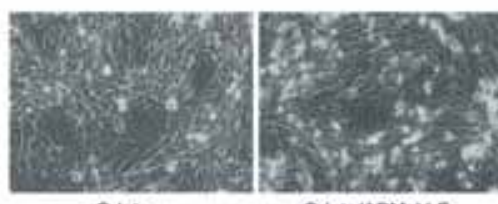

rodateiABMANV-F

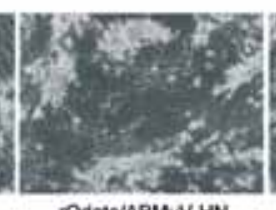

Rodate/ABMUN-HN

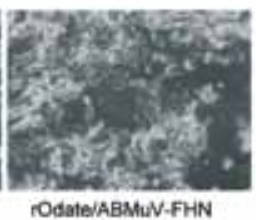

C

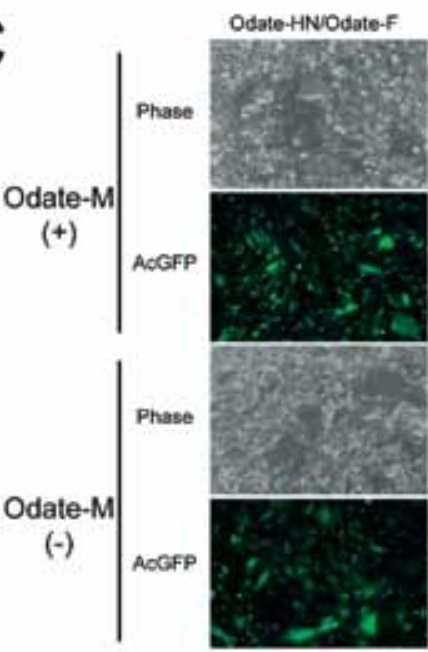

Odate-HNIABMUVF

ABMuN-HNodate-F
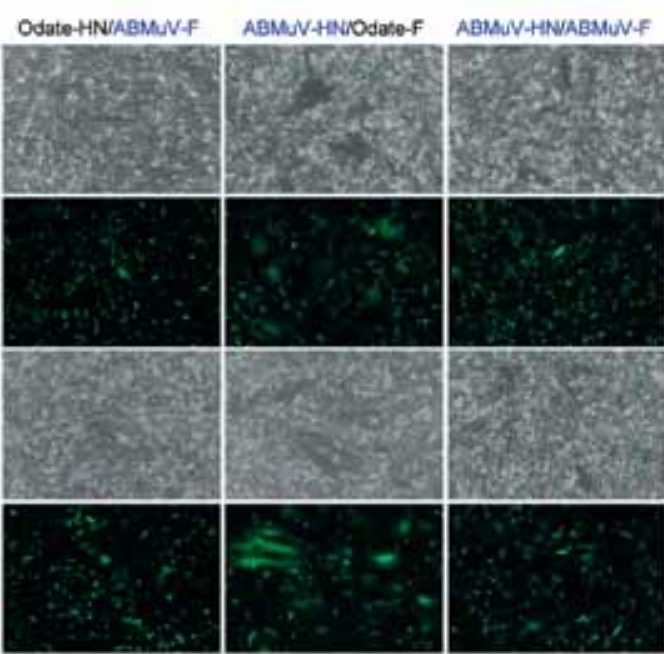

D
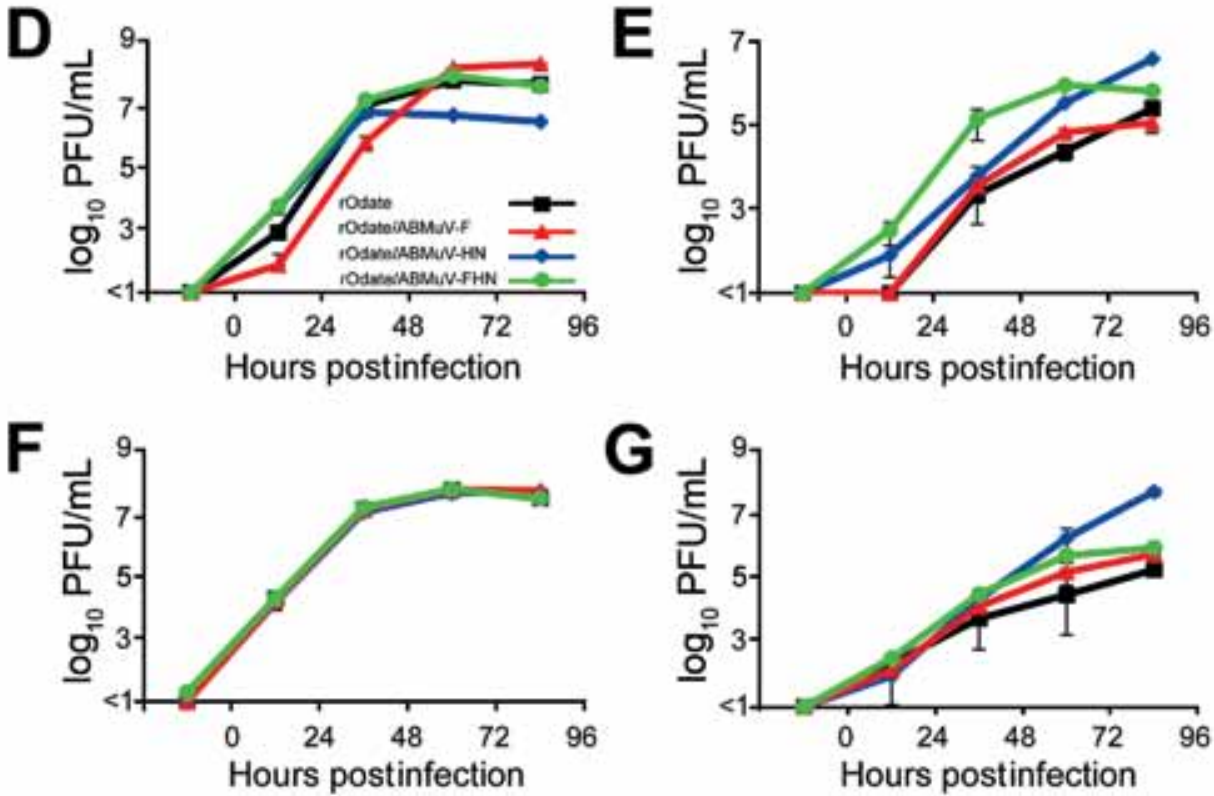

\section{$\mathbf{G}$}

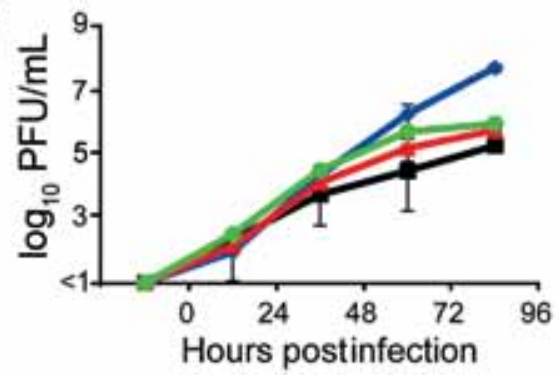

Figure 1. Construction of rMuVs expressing the ABMuV envelope proteins for study of their functions.

A) Genome structures of the rMuVs. The 7 boxes indicate the $\mathrm{N}, \mathrm{V} / \mathrm{P}, \mathrm{M}, \mathrm{F}, \mathrm{SH}, \mathrm{HN}$, and $\mathrm{L}$ genes of MuV. The blue boxes indicate the genes derived from ABMuV. B) Cytopathic effect of rMuV infection of the Vero cells followed by incubation for $48 \mathrm{hr}$. C) BHK cells were transfected with expression plasmids of the $\mathrm{HN}$ and $F$ proteins (pCAGGS-Odate-HN or -ABMuV-HN and pCAGGSOdate-F or -ABMuV-F). They were also cotransfected with expression plasmids of the $M$ protein (pCAGGS-Odate-M) and AcGFP (pAcGFP-C1, Clontech). At $48 \mathrm{~h}$ posttransfection, the cells were observed under a phase-contrast and a fluorescence microscope. D-G) Growth kinetics of the rMuVs in Vero (African green monkey) (D), A549 (human) (E), THP-1 (human) (F) and FBKT1 (Ryukyu fruit bat) $(G)$ cells. Each cell line was infected with the rMuVs at a multiplicity of infection of 0.01 . At the indicated times postinfection, the culture supernatants were collected, and the infectious titers were determined by plaque assay. ABMuV, African bat mumps virus; $\mathrm{F}$, fusion; $\mathrm{HN}$, hemagglutininneuraminidase; L, large; $M$, matrix; N, nucleocapsid; rMuV, recombinant mumps virus; $\mathrm{SH}$, small hydrophobic;

$\mathrm{P}$, phosphoprotein; $\mathrm{V}$, historically considered the fifth viral protein. Error bars indicate SD. 
Table. Mumps virus neutralization test for serum of healthy human adults, Japan*

\begin{tabular}{|c|c|c|c|c|c|c|c|c|}
\hline \multirow[b]{2}{*}{$\begin{array}{l}\text { Serum sample } \\
\text { no. }\end{array}$} & \multirow[b]{2}{*}{$\begin{array}{l}\text { Patient } \\
\text { age, y }\end{array}$} & \multicolumn{2}{|c|}{ Mumps history } & \multirow[b]{2}{*}{ EIA titerł } & \multicolumn{4}{|c|}{ NT titer† } \\
\hline & & Natural Infection & Vaccinated & & rOdate & $\begin{array}{c}\text { rOdate/AB } \\
\text { MuV-F }\end{array}$ & $\begin{array}{c}\text { rOdate/ABM } \\
\text { uV-HN }\end{array}$ & $\begin{array}{c}\text { rOdate/ABMu } \\
\text { V-FHN }\end{array}$ \\
\hline 1 & 32 & Unknown & + & $2^{2.35}$ & 121 & 36 & 133 & 122 \\
\hline 2 & 40 & Unknown & - & $2^{1.36}$ & 21 & 38 & 78 & 109 \\
\hline 3 & 49 & Unknown & - & $2^{2.09}$ & 26 & 7 & 31 & 12 \\
\hline 4 & 48 & + & - & $2^{2.94}$ & 176 & 122 & 183 & 149 \\
\hline 5 & 58 & + & - & $2^{2.80}$ & 41 & 31 & 41 & 33 \\
\hline 6 & 56 & + & - & $2^{2.55}$ & 31 & 8 & 85 & 27 \\
\hline 7 & 40 & Unknown & - & $2^{1.84}$ & 88 & 105 & 58 & 33 \\
\hline 8 & 35 & + & - & $2^{3.32}$ & 186 & 60 & 131 & 118 \\
\hline 9 & 33 & Unknown & - & $2^{2.48}$ & 83 & 30 & 81 & 37 \\
\hline 10 & 31 & + & - & $2^{2.78}$ & 53 & 5 & 122 & 26 \\
\hline 11 & 18 & Unknown & - & $2^{0.74}$ & $<4$ & $<4$ & $<4$ & $<4$ \\
\hline 12 & 18 & Unknown & - & $2^{0.64}$ & $<4$ & $<4$ & $<4$ & $<4$ \\
\hline $\begin{array}{l}{ }^{*} \text { ABMuV, African } \\
-, \text { negative. } \\
\text { †NT titer was de } \\
\text { of serum using th } \\
\text { †Determined by } \\
\text { manufacturer's ir }\end{array}$ & ps vi & $\begin{array}{l}\text { serum that } \\
\text { lench. }\end{array}$ & $\%$ & 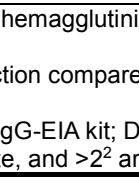 & 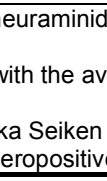 & NT, n & $\mathrm{r}, \mathrm{reco}$ & $\begin{array}{l}\text { nt; +, positive; } \\
\text { n the absence }\end{array}$ \\
\hline
\end{tabular}

Institute of Infectious Diseases. Ten of 12 serum specimens (nos. 1-10) were seropositive or indeterminate (titer $>2^{1}$ ) and neutralized rOdate (NT titer $\geq 4$-fold) (Table). The MuV-NT serum samples showed cross-neutralization between rOdate and 3 chimeric MuVs (Table). Correlations of the NT titers were significant among rOdate and rOdate/ABMuV-F, $-\mathrm{HN}$ and $-\mathrm{FHN}$ of $0.67(\mathrm{p}<0.05), 0.77$ $(\mathrm{p}<0.01)$, and $0.71(\mathrm{p}<0.05)$, respectively, by Pearson product-moment correlation (Figure 2). In addition, serum from a rabbit vaccinated with a genotype $\mathrm{B}$ mumps vaccine strain also neutralized the rMuVs carrying the $\mathrm{ABMuV}$ envelope proteins (data not shown). All data demonstrated that $\mathrm{MuV}$ and $\mathrm{ABMuV}$ were serologically cross-reactive.

\section{Conclusions}

To our knowledge, no infectious $\mathrm{ABMuV}$ has been isolated, although the entire genome sequence was detected in bats. To study the context of virus infection, we generated $\mathrm{rMuVs}$ carrying the $\mathrm{ABMuV}$ envelope proteins by reverse genetics. By using expression plasmids, Kruger et al. reported that the functions, such as fusion, hemadsorption, and neuraminidase activities, of the envelope proteins were conserved and compatible between $\mathrm{MuV}$ and $\mathrm{ABMuV}$ (7). These findings agreed with our data using the recombinant viruses, but notable differences existed. For example, Kruger et al. reported that the $\mathrm{ABMuV}$ envelope proteins induce smaller syncytia than the $\mathrm{MuV}$ proteins, whereas we observed enhanced syncytium formation by $\mathrm{rMuV}$ carrying the $\mathrm{ABMuV} \mathrm{HN}$ protein. However, the enhancement was not due simply to the functional difference between $\mathrm{MuV}$ and $\mathrm{ABMuV} \mathrm{HN}$ proteins because the $\mathrm{HN}$ proteins showed similar fusion-supporting capacities when expressed using expression plasmids. Further investigation of the involvement of other viral proteins modulating the $\mathrm{HN}$ protein function could lead to elucidation of the mechanism underlying this difference. Moreover, although Kruger et al. mentioned that the fusion activity might restrict the viral species specificity, our data indicated that the envelope proteins of $\mathrm{MuV}$ are not critical determinants of the host specificity in cultured cells. Our study also demonstrated that a synthetic genome strategy, which has also been used for the study of a bat influenza virus $(10,11)$, is useful for
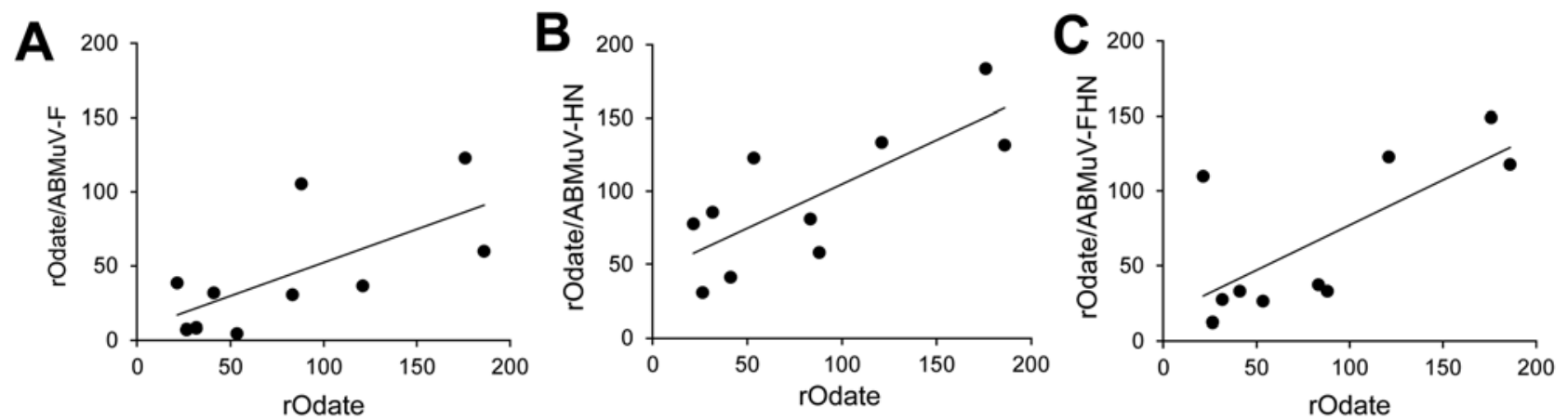

Figure 2. Comparison of the NT titer of rOdate versus rOdate/ABMuV-F (A), -HN (B), and -FHN (C) in a study of serologic crossreactivities. $r$ and $p$ values, calculated by using the Pearson product-moment correlation, are as follows: $(A) r=0.67, p<0.05 ;(B)$ $r=0.77, p<0.01 ;(C) r=0.71, p<0.05$. ABMuV, African bat mumps virus; F, fusion; HN, hemagglutinin-neuraminidase; NT, neutralizing. 
the characterization and risk assessment of emerging viruses, even when the authentic viruses have not been isolated.

Our data showed extensive cross-neutralization between $\mathrm{MuV}$ and $\mathrm{ABMuV}$. Although NT antibodies might play an essential role for $\mathrm{MuV}$ protection, a definitive NT titer for MuV protection is still under debate (12). Cortese et al. suggested that case-patients generally had lower preoutbreak mumps antibody levels than non-case-patients; however, no cutoff NT titer was defined in their study (12). Our findings suggest that antibodies induced by either mumps vaccines or infection with wild-type MuV generally neutralize ABMuV efficiently. Because cell-mediated immunity might also contribute to $\mathrm{MuV}$ protection (13), further investigations are needed to clarify the definitive parameters of $\mathrm{MuV}$ and $\mathrm{ABMuV}$ protection. Nonetheless, our data demonstrate that the current $\mathrm{MuV}$ vaccination program reduces the risk for an emerging infection of $\mathrm{ABMuV}$ in humans.

\section{Acknowledgments}

We thank Naoto Ito and Makoto Sugiyama for providing BHK/ T7-9 cells. We also thank all the members of the Department of Virology III, National Institute of Infectious Diseases, for their technical advice and critical input.

This work was supported in part by grants from the Ministry of Health, Labour and Welfare of Japan.

Dr. Katoh is a senior researcher in the Department of Virology III, National Institute of Infectious Diseases, Tokyo, Japan. His research interests are molecular biology, pathogenesis and pathology, epidemiology, and prevention, and control of mumps virus infection.

\section{References}

1. Drexler JF, Corman VM, Muller MA, Maganga GD, Vallo P, Binger T, et al. Bats host major mammalian paramyxoviruses. Nat Commun. 2012;3:796. Correction in Nat Commun. 2014;5:3032. http://dx.doi.org/10.1038/ncomms1796

2. Lamb RA, Parks GD. Paramyxoviridae: the viruses and their replication. In: Knipe DM, Howley PM, Griffin DE, Lamb RA,
Martin MA, Roizman B, et al., editors. Fields virology. 5th ed. Philadelphia: Lippincott Williams \& Wilkins; 2006. p. 1449-96.

3. Hviid A, Rubin S, Muhlemann K. Mumps. Lancet. 2008;371:93244. http://dx.doi.org/10.1016/S0140-6736(08)60419-5

4. World Health Organization. Mumps virus nomenclature update: 2012. Wkly Epidemiol Rec. 2012;87:217-24.

5. Tsurudome M, Yamada A, Hishiyama M, Ito Y. Monoclonal antibodies against the glycoproteins of mumps virus: fusion inhibition by anti-HN monoclonal antibody. J Gen Virol. 1986;67:2259-65. http://dx.doi.org/10.1099/0022-1317-67-10-2259

6. Šantak M, Örvell C, Gulija TK. Identification of conformational neutralization sites on the fusion protein of mumps virus. J Gen Virol. 2015;96:982-90. http://dx.doi.org/10.1099/ vir. 0.000059

7. Krüger N, Hoffmann M, Drexler JF, Müller MA, Corman VM, Sauder C, et al. Functional properties and genetic relatedness of the fusion and hemagglutinin-neuraminidase proteins of a mumps virus-like bat virus. J Virol. 2015;89:4539-48. http://dx.doi.org/ 10.1128/JVI.03693-14

8. Saito H, Takahashi Y, Harata S, Tanaka K, Sano T, Suto T, et al. Isolation and characterization of mumps virus strains in a mumps outbreak with a high incidence of aseptic meningitis. Microbiol Immunol. 1996;40:271-5. http://dx.doi.org/ 10.1111/ j.1348-0421.1996.tb03346.x

9. Rubin S, Eckhaus M, Rennick LJ, Bamford CG, Duprex WP. Molecular biology, pathogenesis and pathology of mumps virus. J Pathol. 2015;235:242-52. http://dx.doi.org/10.1002/path.4445

10. Juozapaitis M, Aguiar Moreira E, Mena I, Giese S, Riegger D, Pohlmann A, et al. An infectious bat-derived chimeric influenza virus harbouring the entry machinery of an influenza A virus. Nat Commun. 2014;5:4448. http://dx.doi.org/10.1038/ncomms5448

11. Zhou B, Ma J, Liu Q, Bawa B, Wang W, Shabman RS, et al. Characterization of uncultivable bat influenza virus using a replicative synthetic virus. PLoS Pathog. 2014;10:e1004420. http://dx.doi.org/10.1371/journal.ppat.1004420

12. Cortese MM, Barskey AE, Tegtmeier GE, Zhang C, Ngo L, Kyaw MH, et al. Mumps antibody levels among students before a mumps outbreak: in search of a correlate of immunity. J Infect Dis. 2011;204:1413-22. http://dx.doi.org/10.1093/infdis/jir526

13. Vandermeulen C, Leroux-Roels G, Hoppenbrouwers K. Mumps outbreaks in highly vaccinated populations: What makes good even better? Hum Vaccin. 2009;5:494-6. http://dx.doi.org/10.4161/ hv.7943

Address for correspondence: Makoto Takeda, Department of Virology III, National Institute of Infectious Diseases, 4-7-1 Gakuen, Musashimurayama-shi, Tokyo 208-0011, Japan; email: mtakeda@nih.go.jp

\section{Medscape sign up to recieve email announcements CME when a new article is available.}

